\title{
The Effectiveness of Process Approach in Developing German Teaching Writing Materials
}

\author{
Dulciana Chaty Engelhart Hitipeuw ${ }^{1}$, Emzir $^{2}$, Kinayati Djojosuroto ${ }^{3}$ \\ \{dulcianahitipeuw@yahoo.de ${ }^{1}$, Emzir.unj@unj.ac.id ${ }^{2}$, Kinayati_dj@yahoo.com ${ }^{3}$ \} \\ Universitas Negeri Jakarta, Indonesia ${ }^{123}$
}

\begin{abstract}
This study aims at developing German writing materials based on process approach for the fifth semester students of German Department of the Faculty of Language and Art at Universitas Negeri Manado in Indonesian. It adapted Research and Development (R\&D) cycle by Borg and Gall. The collected data was displayed and supported by t-test. The research findings show that process approach of German writing materials is effective and efficient to be used. From the critical table of $t$, the score of $t_{\text {calculated }}$ for df. 15 is 12,164 by pvalue $=0.000<0.05$. It means $\mathrm{H}_{0}$ rejected and $\mathrm{H}_{1}$ accepted. Based on this criterion the hypothesis is accepted. It can be concluded that process writing approach gives significant influence on the student's ability.
\end{abstract}

Keywords: effectiveness, process approache, writing materials

\section{Instroduction}

A Swiss writer named Verena Stefan said, that writing is always a work in language. Holistically, writing is an ability which cover the ability of thinking, think about the content of the writing, think about thr numbrt of vocabulary needed in writing, thinking about the accuracy of using linguistic aspects, thinking about the placement of punctuation used, thinking about the meaning of writing that is read by others. According to the opinion of Al-Jumaily [1] writing is a skill that produces important language like talks, that is how to communicate with other people in delivering the meaning, express thoughts, feelings, and opinions in writing that is well-organized, clear, and interesting. On the other hand according to Stroch [2], when compared to speaking, writing is a slow process that deals with strong cognitive activity is the process of thinking about the contents of the writing, expressions, grammar forms, need to pay attention to the accuracy of grammar, and intensive need to be controlled when actively writing. Because of that Krumm said [3] that writing is very closely related to the expansion of ways of thinking, also closely related to the principles of order, because writing actually helps us to organize and to compose our thoughts that are messy, which is not systematic.

However writing is still seen as the most difficult language skill compared to other language skills, both studentsd first and second language, Zhou [4], Bayat [5], and generally a major challenge [6], Göy [7]. .According to Brown[8] second language learning is a long and complex job. The whole self is affected when struggling beyond the boundaries of the first language and trying to reach a new language, new culture, and new ways of thinking, feeling, and acting. Total commitment, total involvement, physical response, intellectual, and total of emotional is needed for the success of sending and receiving messages in the second language. According to Ferling 
[9] usually the components of the first language greatly influence the activities of writing in foreign languages as a second language, which are mastery of syntax, morphological, lexical, the use of spelling that is different from student's first language. This difference causes the students in the German Language Education Study Program at Manado State University to have difficulty in writing German texts.

In addition, writing is judged by the results of student writing, not on what students should do while writing. Students are given one theme and immediately do writing activities, without first learning about how to write to get good and appropriate writing results. The habit that occurs after the writing activity is that the student's writing is collected, corrected with and marked with a red, green or blue pen, and immediately rated by the teacher. Learning habits that are carried out like caused the students feeling bored, lacking in enthusiasm and doing writing activities as a condition of attending a writing course. Because the assesment and writing errors are more directed at grammatical errors, Bräuer [10] emphasizes, writing is the result of grammar tests that reveal less about how to write than their mistakes._Altendorf [11] emphasizes, learners with learning difficulties cannot obtain satisfaction from their own writing skills which of course has a negative effect on motivation, writing performance that can be a cause of writing skills is ignored in learning. Instead wrote Barnett [12], teachers and students benefit from treating writing activities as a mental process and means of communication.

Another challenge in writing activities is the lack of special teaching materials about writing, although the teaching materials used by students and teachers come from major publications in Germany. Groh [13] conducted a study of several German textbooks used in teaching German as a foreign language, as evidenced by the fact that the textbooks prioritized teaching books prioritizing verbal communicative aspects, so listening skills and speaking skills were more important than with writing skills. Ghazali explained, [14] writing is a secondary skill whose importance is below the ability to listen, speak and read.

According to Williams [15] and Philip [16] even now writing as one of the productive skills, has not fully received serious attention in learning foreign languages.

Brinitzer at all [17]] explained that writing is complex and anxious. Therefore, a good relief for writing activities is extremely important. One effort to create a pleasant learning atmosphere, as well as improving the quality of student writing is to inovate teaching materials in writing German texts based on the process approach according to the needs of students. Teaching materials according to Quetz [18] distribute important pedagogic knowledge that provides motivation, innovation in learning, because besides teacher, teaching materials are the most important controlling factor in the learning process. Teaching materials also provide linguistic material that is combined with other forms of training that are expected to stimulate students' mental processes. Tomlinson [19] explains, teaching materials can be instructional, experiential, elitist, exploratory which informs learners about the language itself, provides experience in language use, as well as using language, and then helps learners make their own discoveries about language. In this study a teaching material for writing German texts was developed based on the process approach used by students in the German Language Education Program at Manado State University.

Writing based on process approach has a goal, according to Altendorf [11] is to promote and communicate strategies and learning techniques in order to optimize the process of a writing activity. This is different with the writing based on product approach, Nunan [20] explain that 
writing baded on process approach prioritizes activities carried out through processes to develop language skills. It is more focused on quantity values than quality, where students as writers are encouraged to convey ideas poured on paper without the need to worry about formal corrections from the instructor. This approach encourages cooperation between students as a form of activity to increase motivation and develop positive attitudes towards writing.

The process of writing in class is very structured because it requires regular teaching from process skills. The design of the writing is arranged systematically according to the stages of the writing process. The stages that must be passed according to the writing process approach, consist of planning, drafting, editing, Hermer's final draft [11], Glass [21] added self-review and peer revision, revising, and publishing, and Seow [22] added an evaluation stage. Kast [22] offers a process-oriented writing learning model with five stages detailed into seven stages. The five stages are: (1) control of the writing task, (2) preparation of a writing plan, (3) preparatory formulation, (4) transcript of the text, and (5) revision phase.

The stages in developing materials learned to write German texts developed according to Kast by adding publishing step. The steps for developing process-based German language texts are as follows:

At the first stage, students were introduced, the reason of writing the text, the type of text written, the content of the text, the purpose of communication to be approved, the reason for writing, whoever writes about anyone, the role relationships (between friends, readers and newspapers, superiors and subordinates, etc ).

In the second stage, students are prepared through discussion of themes and new content to be written. Early knowledge of students relate to the new themes and content to be written, activated, and related content that has just been developed, for example in the form of assosiogram, cluster, brainstorming, text evaluation, "wh-question" questions. At the same time, student linguistic knowledge about new themes are also activated and updated. According to Brinitzer at all [23], assosigram is a model of combining images, words, phrases, acceptance of very open theme languages that are practically used at the level of language learning. Assosiogram activities are carried out through various methods discussed in small groups and discussed in general.

In the third stage, the planning phase of the writing focused on bringing students to a theme that is written. At this stage the forms of training are still presented as an introduction to the theme to be written, depending on the type of text. For example, answering questions about reading, constructing loose sentences into one whole text, done in groups. At this stage, the analysis phase of the text that has been prepared is also done, specifically analyzing the place information, a description of the time that will be used in the text to be written. The introduction of linguistic aspects is analyzed to help students complete the text that is written.

In the fourth stage, students design a text from the previous step in the second and third stages. While writing text students need to pay attention to vocabulary aspects (more complex sentences, inter-sentence relations, use of conjunctions, and other aspects of cohesion. The quality of the type of text such as writing a formal or personal letter must be discussed before, if necessary introduced and explained for pay attention to punctuation.

In the fifth stage, after writing, the students immediately see the results of the writing with the help of checking the list, whether they write the discussion items, are the points in writing a letter not forgotten to be written by them?, whether between one sentence and another use the right 
conjunctions. Is the use of the time and place appropriate and according to German grammar? After the correction of the results of writing, the students' writing is given to the other classmate to be read and corrected. At the end of the activity, the teacher in general discussed together with the students about the mistakes that they made, and the students corrects the mistake.

In sixth stage, the revised writing that has been rewritten for the second time, read in front of the class, or hung on a board in front of the class for all classmate to read.

\section{Methodology}

This study used a development research design developed by Borg and Gall [24]. The development research procedure consists of three main stages, namely preliminary research, teaching material development planning, and evaluation. Preliminary research activities include (a) observation, (b) identification of teaching material needs, (c) documentation. Activities for planning and developing teaching materials include, (a) collecting and selecting teaching materials collected, (b) designing teaching materials and developing them. Early stage, the evaluation activity is carried out to determine the feasibility of the instructional materials developed. Evaluation activities include expert test, main field test and product effectiveness test. Completion of the test activities is completed. Test the effectiveness of writing instructional materials based on the process approach in the form of pre-test and post-test in one student group. Data obtained in the form of the ability to write before applying the product and the ability to write late after applying the product. Developing process-based on writing teaching materials, the authors followed the stages proposed by Jolly and Bolitho [25] (1) identification of need for German writing materials based on process, (2) exploration of students need, (3) contextual realization of German teaching writing material, (4) pedagogical realization of materials, (5) production of matetials, (5) students use of materials, and (6) evaluation of materials against agreed objectives.

The target of the study was 16 students at fifth-semester of the German Language Education Program, Language and Arts Faculty of Universitas Negeri Manado in Tondano who took the Schrisftlicher Ausdruck 1 course, the 2014-2015 school year.Data analysis in this study used quantitative data, analysis t-test. Statistical analysis of t-test using SPSS with Paired Samples Test formula. The research data set can be accessed in osf.io Open Science Framework

\section{Results and Discussion}

The researcher used the analysis of the difference in the two sample averages because it used the value data from the pretest and posttest results that came from one sample group which produces two data distribution. Parametic statistics are used to test German writing teaching materials based on the process approach using SPSS through the t-test using the Paired Sample Test formula. The results of the effectiveness of writing teaching materials can be seen in the following tables 1 . 
Table 1: Paired Samples Statistics

\begin{tabular}{|rr|r|r|r|r|}
\hline & & \multicolumn{1}{|c|}{ Mean } & N & \multicolumn{1}{|c|}{ Std. Deviation } & \multicolumn{1}{|c|}{ Std. Error Mean } \\
\hline \multirow{2}{*}{ Pair 1 } & Pretest & 12,8750 & 16 &, 80623 &, 20156 \\
& Posttes & 8,4375 & 16 & 1,09354 &, 27339 \\
\hline
\end{tabular}

In the Paired Samples Statistics table above, it can be seen that the average value of the written test results before being given the process approach is 12.8750 with Standard Deviation 0.80623 amounting to, 20156. While the Standard Error mean is 0.20156 . While the average writing test results after being given a German writing process based on the process approach is 8.4375 with standard deviation 1.09354 and the standard erros mean, 27339. From the analysis of the data obtained can be interpreted that descriptively, there are differences in the average value of the German writing test students before and after teaching materials written in German based on the process approach.

Table 2: Paired Samples Statistics

\begin{tabular}{|rl|r|r|r|r|}
\hline & & \multicolumn{1}{|c|}{ Mean } & N & \multicolumn{1}{|c|}{ Std. Deviation } & \multicolumn{1}{|c|}{ Std. Error Mean } \\
\hline \multirow{2}{*}{ Pair 1 } & Pretest & 12,8750 & 16 &, 80623 &, 20156 \\
& Posttes & 8,4375 & 16 & 1,09354 &, 27339 \\
\hline
\end{tabular}

In the Paired Samples Correlation table, there is a correlation coefficient value of the results of the writing test before and after the process approach is given at -0.161 with significant numbers or $\mathrm{p}$ value $=0.55250 .05$ or significant.

Tabel 3. Paired Samples Test

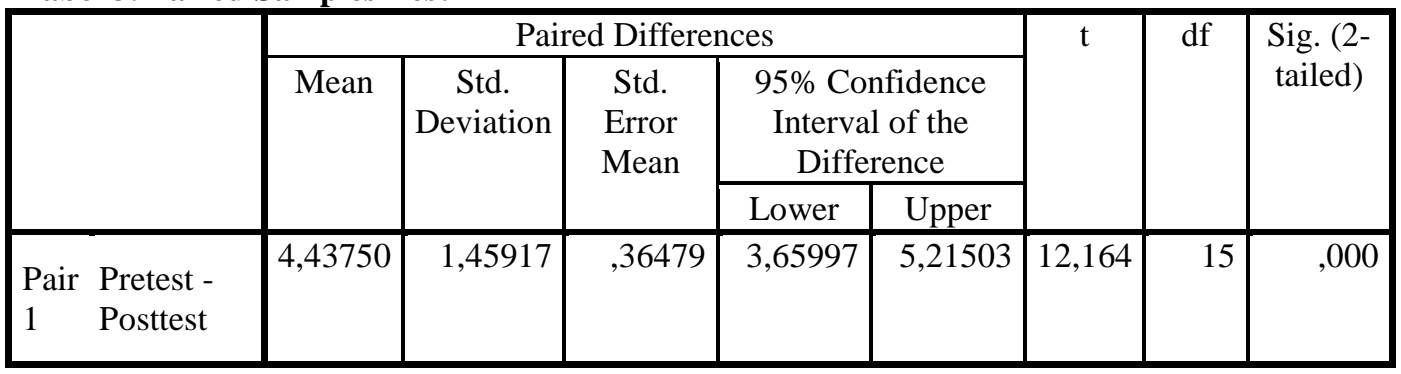

$\mathrm{H}_{0}: \mu 1=\mu 2$

$\mathrm{H}_{1}: \mu 1 \neq \mu 2$

$\mathrm{H}_{0}$ is rejected, if calculated $>\mathrm{t}$ table.

$\mathrm{H}_{0}$ : there is no difference in the learning outcomes of the pretest and posttest

$\mathrm{H}_{1}$ : there are differences in the learning outcomes of the pretest and posttest

Based on paired samples statistics the average pretest learning outcome is 4.437 while the posttest learning results are 12.875. This means that descriptively there are differences in the average 
learning outcomes of the pretest and posttest or the posttest learning outcome value greater than the value of the pretest. The difference in pretest and posttest learning outcomes was 4.4375, with a value of tcount12.164, $\mathrm{t}$ table 2.13 and a p-value of 0.000 . Therefore, the average learning outcome of the pretest is not the same as the posttest $(\mu 1 \neq \mu 2)$, the $t$ calculated is greater than the $t$ table and the $\mathrm{p}$-value is $<0.005(0,000<0.05)$. The results of data analysis show, reject $\mathrm{H}_{0}$, and accept $\mathrm{H}_{1}$.

Based on the results of the effectiveness tests conducted, it can be shown that there is a significant difference between the scores of the writing test results of the German Language Education Study Program which were significant between before and after the process approach was given. It can be known that the process approach applied in effective writing teaching is to improve students' ability to write German. Writing teaching materials with a process approach is a new approach applied to students in the German Language Education Program. The development of writing teaching materials based on this process makes students more enthusiastic, motivated, passionat and feel happy to be involved in writing German texts that were previously a scourge for them. Although difficulties arise among students when trying to correct a colleague's writing, they feel uncomfortable, reluctant, afraid, and hesitant, because correcting a friend's writing is the first time this has not been done before.

\section{Conclusion}

Based on the results of the effectiveness carried out, it can be concluded that there are differences in the value of the results of writing German students before and after the application of the process approach is very significant. It can be concluded that teaching materials in writing German based on an effective process approach to improving student writing.

\section{References}

[1] S. Al-Jumaily, "Improving My Students' Writing Skill: An Intensive Course for ESL Learners by Using Process-Approach to Writing with the Assistance of Computer Word Processor,” Int. J. English Lang. Teach., vol. 2, no. 1, p. 29, 2014.

[2] G. Storch, Deutsch als Fremdsprache-Eine Didaktik: Theoretische Grundlagen und praktische Unterrichtsgestaltung, vol. 8184. UTB, 1999.

[3] H.-J. Krumm, H. J. Krumm, P. R. P.-T. Hg, and K. Fertigkeiten, "FREMDSPRACHE DEUTSCH!," J. Pragmat., vol. 11, pp. 211-247, 1987.

[4] D. Zhou, "An Empirical Study on the Application of Process Approach in Non-English Majors' Writing," English Lang. Teach., vol. 8, no. 3, p. 89, 2015.

[5] N. Bayat, "The Effect of the Process Writing Approach on Writing Success and Anxiety.," Educ. Sci. Theory Pract., vol. 14, no. 3, pp. 1133-1141, 2014.

[6] I. Leki, "The preferences of ESL students for error correction in college-level writing classes," Foreign Lang. Ann., vol. 24, no. 3, pp. 203-218, 1991.

[7] N. Göy, "An action research on the development of self-regulated writing strategies of Turkish EFL students,” Eurasian J. Appl. Linguist., vol. 3, no. 2, pp. 191-204, 2017. 
[8] H. D. Brown, "Prinsip pembelajaran dan pengajaran bahasa," Amerika Pearson Educ., 2008.

[9] S. Kaufmann, Fortbildung für Kursleitende Deutsch als Zweitsprache: Didaktik, Methodik, vol. 2. Hueber Verlag, 2008.

[10] G. Bräuer, "Schreiben im Fremdsprachenunterricht?," Die Unterrichtspraxis/Teaching Ger., pp. 1-7, 1997.

[11] J. Altendorf, Schreiben in der Fremdsprache-theoretische Grundlagen des Schreibprozesses und praktische Vorschläge für das Training der Fertigkeit'Schreiben'im Englischunterricht der Sekundarstufe I. GRIN Verlag, 2008.

[12] M. A. Barnett, "Writing as a process," French Rev., vol. 63, no. 1, pp. 31-44, 1989.

[13] M. Maijala, "Was ein Lehrwerk können muss-Thesen und Empfehlungen zu Potenzialen und Grenzen des Lehrwerks im Unterricht Deutsch als Fremdsprache," Informationen Deutsch als Fremdspr., vol. 34, no. 6, pp. 543-561, 2007.

[14] S. Ghazali, "Pembelajaran keterampilan berbahasa dengan pendekatan komunikatifinteraktif," Bandung: Refika Aditama, 2010.

[15] J. Williams, "The potential role (s) of writing in second language development," J. Second Lang. Writ., vol. 21, no. 4, pp. 321-331, 2012.

[16] M. Philipp, Schreibkompetenz: Komponenten, Sozialisation und Förderung, vol. 4457. UTB, 2015.

[17] M. Brinitzer, DaF unterrichten: Basiswissen Didaktik Deutsch als Fremd-und Zweitsprache. Ernst Klett Sprachen GmbH, 2016.

[18] J. Quetz, "Lehrwerkforschung als Grundlage der Lehrwerkkritik," 1999), Erforsch. von Lehr-und Lernmaterialien des Lehrens und Lernens fremder Sprachen. Tübingen Narr, 1999.

[19] B. Tomlinson, Developing materials for language teaching. A\&C Black, 2003.

[20] D. Nunan, Language teaching methodology. .

[21] K. T. Glass, GLASS, Kathy Tuchman. Curriculum design for writing instruction: Creating standards-based lesson plans and rubrics. Corwin Press, 2004.

[22] A. SEOW, "The writing process and process writing. Methodology in language teaching: An anthology of current practice," pp. 315-320, 2002.

[23] G. STORCH, "Deutsch als Fremdsprache-Eine Didaktik: Theoretische Grundlagen und praktische Unterrichtsgestaltung."

[24] J. P. GALL, Meredith Damien; BORG, Walter R.; GALL, "Educational research: An introduction."

[25] R. JOLLY, David; BOLITHO, "A framework for materials writing. Materials development in language teaching." 